\title{
MODERN TEST METHODS FOR FLAMMABILITY
}

\section{Vytenis Babrauskas}

U.S. DEPARTMENT OF COMMERCE Natlonal Institute of Standards and Tochnology Center for Fire Research Galthersburs, MD 20899

U.S. DEPARTMENT OF COMMERCE Robert A. Mosbachor, Secrotary MATIONAL INSTITUTE OF STANDARDS AND TECHNOLOQY

John W. Lyons, Director

\section{NاكT}




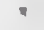




\section{MODERN TEST METHODS FOR FLAMMABILITY}

Vytenis Babrauskas

U.S. DEPARTMENT OF COMMERCE Natlonal Institute of Standards and Technology Conter for Fre Research Galthersburg, MD 20899

June 1990

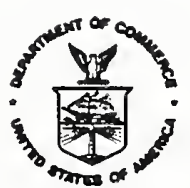





\title{
MODERN TEST METHODS FOR FLAMMABILITY
}

\author{
Dr. Vytenis Babrauskas \\ Center for Fire Research \\ National Institute of Standards and Technology \\ Gaithersburg, MD 20899
}

\begin{abstract}
During the last decade, significant improvements have become available in flammability testing. Rationally-based new methods, derived from fundamental engineering principles are replacing the previously used empirical tests. The major emphasis in this development work has been to provide a basic set of bench-scale methods which can be used to predict full-scale product performance. Reference methods for conducting full-scale tests. will continue to be needed to handle products or situations where the bench-scale methods are not applicable. The bulk of the testing needs, however, can now be fulfilled by use of bench-scale tests which are not only simple to run, but are known to predict accurately the full-scale performance.
\end{abstract}

Keywords: bench-scale tests; fire corrosivity; fire toxicity; heat release rate; smoke; test methods.

\section{INTRODUCTION}

There is currently a huge number of available national test methods for fire testing. For example, one such compilation of only the ASTM methods on fire [1] tabulates some 77 tests! Based on this, the person new to the fire testing area might conclude that fire test methods are highly-refined, well-tuned to specific areas, and that he or she only has to find the right-fitting one. Of course, the reality is very different. The methods on the books have, in many cases, been developed 40 years ago, did not rely on any understanding of the physics of the situation being represented, and present their results as totally arbitrary numbers. Meanwhile, during the last decade or so, sound, physicsbased design methods have come- to be available to the fire engineer. These methods include both simpler, closed-form calculational formulas and complete computer fire models. An example is the HAZARD I model [2], which may be the most ambitious such method yet made available for general design purposes.

Such computer fire models require as input data variables which have not been available from traditional test methods. In some other cases, the requisite data may have been available from existing tests, but had unacceptable errors associated with them. During the last few years, methods to address these needs have either been developed or, in some cases, are at least under active development. In this paper we will examine some of these new methods, consider their salient features, and illustrate how they can be used in quantitative studies. Emphasis will be laid on quantitative techniques for predicting full-scale behavior from bench-scale test results. In view of the increased prominence of international standards, we will also emphasize the methods being developed by the International Organization for Standardization (ISO). 


\section{BACKGROUND}

During the 1940's and the 1950's flammability (or "reaction-to-fire") tests were developed on a purely ad hoc basis. Results were typically expressed as arbitrary 0 to 100 scales, or, even worse, by such rating terms as "self-extinguishing." In 1973 the U.S. Federal Trade Commission saw such practices as misleading and sued a number of plastics manufacturers and also ASTM [3]. As a consequence, ASTM was forced to withdraw certain test methods and to modify others. It was appropriate to deprecate such misleading use of bench-scale test methods; however, the question then came up - What is the user to do? Not only were better bench-scale test methods not on the books, but neither were there any suitable full-scale test methods. As we shall see below, appropriate full-scale tests did eventually get developed and become available. These are, in fact, the only touchstone of reality and therefore have a unique role in fire testing. Nonetheless, it would be exceedingly costly and difficult to conduct all necessary testing solely by full-scale tests. Thus, bench-scale tests are necessary; but they are useful only if they are valid, thus we will focus strongly on efforts at providing such validation.

We may note that the situation in other countries has been no better. More than ten years ago, Prof. Emmons obtained the results of flammability tests on a number of materials, when tested according to various national, bench-scale flammability standards [4]. Not surprisingly, he found that the relationship between the test results according to the different standards was almost completely random. Ostman and Nussbaum [5] very recently returned to re-examine this issue; the situation is seen to be improved only slightly. The reason is, of course, that the new knowledge gained in fire physics and engineering over the last 10 or 15 years has generally not yet been reflected in the required tests which are on the books.

\section{ROOM FIRE TESTS}

The role of the full-scale room fire test method is rather special. The full-scale method is the only kind that can have intrinsic validity, without reference to another method. It still is required that the fire scenario used in the test be a good representation of the actual hazard, that the instrumentation and test arrangements be competently done, and so forth. Once these points are assured, a full-scale room fire test that is conducted is the true representation of reality. Any other tests can only be considered valid if they are validated against such full-scale room fire tests.

Room fire tests of various types have been conducted for quite some while. The measurements made from them, however, did not have much general useability. The main reason was that neither mass loss rates nor heat release rates could be successfully measured in the typical room fire test of the early 1970's. The heat release rate is, of course, the single most important measure of a room fire, since it quantifies the question How big is the fire? The subsequent development of the oxygen consumption principle, which is described below, did allow for the development of useful, standardized room fire tests.

ASTM published in 1982 [6] a draft proposal for such a standard room fire test, where the heat release rate would be measured by oxygen consumption. The room was $2.4 \mathrm{~m}$ wide, by $3.7 \mathrm{~m}$ long, and $2.4 \mathrm{~m}$ high, with a single doorway opening in one wall, $0.76 \mathrm{~m}$ wide by $2.03 \mathrm{~m}$ high. The test method prescribes a standard ignition source, which is a gas burner, placed in a rear corner of the room, giving an output of $176 \mathrm{~kW}$. The method is primarily intended for testing combustible wall and ceiling linings, although floor-standing combustibles could also be tested. Figure 1 shows the ASTM room fire test. 
ASTM has not, as of this date, adopted this method as a formal standard. NORDTEST, however, has adopted a room fire test method quite similar to the one which was proposed by ASTM. The NORDTEST method [7] uses a room of essentially the ASTM dimensions, 2.4 by $3.6 \mathrm{~m}$ by $2.4 \mathrm{~m}$ high, with an 0.8 by $2.0 \mathrm{~m}$ doorway opening. The NORDTEST method uses a gas burner set to the $100 \mathrm{~kW}$ level. If no ignition is achieved in 10 minutes, the heat output is then raised to $300 \mathrm{~kW}$. The NORDTEST room fire tests forms the basis of the method being currently considered by the ISO (the International Organization for Standardization) [8].

\section{OXYGEN CONSUMPTION PRINCIPLE}

It has long been known that there is an empirical relationship between the amount of heat produced in combustion systems and the oxygen consumed from the air stream. While this knowledge, in fact, dates to the turn of the century, the foundation for using the principle in fire test methods is based on the works of Huggett and Parker. Huggett [9] made a detailed study of a wide variety of materials. He found that for most combustible materials, which included polymers, organic liquids, and natural materials, $13.1 \mathrm{MJ}$ of heat is released for each $\mathrm{kg}$ of oxygen consumed from the air. Deviations from this average value are typically on the order of only $\pm 5 \%$. (It must be emphasized that this constant must not be confused with the heat of combustion, which is defined as the heat released, per $\mathbf{k g}$ of fuel consumed. Heats of combustion for common materials vary readily by a factor of 2 and more and would not be considered at all constant.)

Huggett also noted that the material does not need to burn fully to $\mathrm{CO}_{2}$ for the above relationship to hold. Typical reactions yielding part of the combustion products as $\mathrm{CO}$ or as soot do not significantly affect the accuracy of the results. The constant $13.1 \mathrm{MJ} / \mathrm{kg} \mathrm{O}_{2}$ holds very closely for all hydrocarbons ( $\mathrm{C}, \mathrm{H}$ materials) with only a very few exceptions. These exceptions are known, e.g., the value for acetylene is 15.7. For combustibles which have significant fractions of $\mathrm{O}, \mathrm{N}, \mathrm{Cl}, \mathrm{Br}, \mathrm{F}$, or $\mathrm{S}$, the relationship may be less exact. Detailed values of this constant are tabulated for many combustibles [10].

The basic understanding of the oxygen consumption principle is simple: For each Joule of combustion heat generated, there is a fixed number of oxygen molecules that are removed from the exhaust stream. This understanding immediately makes it clear that the results of the method are unchanged when one changes the exhaust rate of the combustion products, or if one introduces an additional dilution stream. Neither an additional stream nor a changed flow rate will change the number of oxygen 'holes' travelling through the system. In practice, one does not count oxygen molecules; rather, measurements of flow rate and oxygen concentration are made. Thus, there are some practical limits to the extent of possible dilution if the resultant data are not to be noisy. The actual implementation of the oxygen consumption equations has to be concerned with matters such as the mole change between the inflow and the outflow streams, trapping of certain species from gas analyzer lines, and so forth. The resultant equations are not necessarily simple, but they have been worked out in detail by Parker [11] for most conditions of concern. These equations are the starting point for the implementation of apparatuses based on oxygen consumption calorimetry. 


\section{HEAT RELEASE - LARGE SCALE}

The ultimate in large-scale testing is full room fires, as discussed above. In such a test, all of the combustion products are collected through a large hood, where oxygen concentration and flow rate measurements are used to compute the instantaneous heat release rate. For a combustible wall lining, this is the only way that a proper full-scale test can be conducted. For floor-standing combustibles, that is, furniture, furnishings, stored goods, etc., a simpler test can be conducted. It was empirically demonstrated [12] that the heat release rate of a furniture item is generally the same, whether the item is in a fully-furnished room, or if it is burned out in the open. There are limitations to this relationship, and the reader interested in those details should consult the original reference.

The realization that it is possible to obtain heat release data in an open-burn test allowed a family of apparatus, generally termed 'furniture calorimeters,' to be designed. At NIST, the first such device was described in 1982 [13]. More recently, NORDTEST have adopted a similar scheme and have issued a standard, the NORDTEST NT FIRE 032 [14]. Figure 2 shows a view of the NORDTEST furniture calorimeter. The apparatus consists primarily of an instrumented exhaust duct system. In the exhaust duct, flow rate and oxygen concentration are measured, allowing the heat release rate to be computed. Additional gas analyzers can also be used to measure $\mathrm{CO}, \mathrm{CO}_{2}$, and other gases of interest. The exhaust stream also contains a smoke photometer for measuring the smoke being evolved from the specimen. Finally, a load cell is used to determine the specimen's mass loss rate. When combined with the heat release rate, an effective heat of combustion can then also be computed.

The basic variable measured in the furniture calorimeter is the heat release rate. For full-scale testing, this has the units of $\mathrm{kW}$. Also, the total heat released during the entire test can be computed, using the units of MJ (megajoules).

\section{THE DESIGN OF BENCH-SCALE FIRE TEST METHODS}

In general, bench-scale tests can be used to serve at least three different purposes:

1) prediction of expected full-scale behavior

2) quality control assurance in manufacturing

3) guidance in product development.

Objective \#2, tests for quality control (QC), traditionally constituted a very large family of tests. Here the requirements are that the test must be highly sensitive to small variations in the specimen's physical or chemical properties, that it be well-repeatable, and that it be simple and inexpensive to conduct. It is especially important to note that stringent rules of validity are not required for tests to meet this objective. A much looser requirement for validity here is merely that most productionline changes, which can possibly occur in manufacturing and which could affect the flammability of the specimen, should be reflected in a statistically significant deviation in the test's results. Tests for objective \#3, guidance in product development, can vary greatly and do not, in principle, need to be standardized at all, since they are to be used only internally within an organization.

Tests conforming to objective \#1 are the most difficult to develop. The tests of the 1950's or the 1960 's were applied to full-scale fires typically not by any quantitative understanding of the full-scale fire, but by merely asserting that a certain test shall be deemed usable in this context. This, we now 
realize, is not adequate. Better understanding of the physics has now allowed starting development of an entirely new generation of tests.

There are two ways that fire tests can be designed and utilized to meet objective \#1. The first is a fully -rigorous determination of material fire properties by specific tests, then the actual prediction of fire performance by a computer simulation of the room fire. Computer predictive methods are expected to assume ever-increasing importance for design applications; however, such applications, as of 1990 , are still not common. We will mention this approach occasionally, but we will see that practical progress requires a second approach. This second approach, while less rigorous, is one that can be used by the practitioner today. It is founded on predictive equations which are partly physicsbased and partly based on data correlations. The steps required to produce such a correlational method can be summarized [15],[16]:

(i) Identify the governing physical and chemical principles of the phenomenon to be measured.

(ii) Design a candidate bench-scale test using these principles.

(iii) Identify the range, best to worst, of relevant full-scale product behaviors and assemble specimens having those expected traits.

(iv) Assemble a data base by testing this range of specimens at full-scale, and gather data using instruments appropriately designed to measure the governing physical and chemical phenomena.

(v) Conduct bench-scale tests, varying those features of fire behavior which cannot be assigned known constant values.

(vi) Attempt to correlate the bench-scale results against the full-scale data base not only by ranking but also for quantitative values.

(vii) Select those bench-scale test protocol features which lead to the best correlation with the full-scale data.

For using either a complete room fire model or for developing a correlation method, it is necessary that the different aspects of fire be understood and isolated. These are taken to be [17]:

- ignition

- flame spread

- rates of heat release and production of smoke, toxic gases, and corrosive products

Based on this categorization, we will now examine the newer bench-scale methods which have become available due to the improved understanding of fire physics.

\section{IGNITION}

Ignition here will be assumed to be from an external source of heat or fire. In some design cases, a unique ignition source will be seen to exist. In many other cases, the substance can be ignited from several different external events. It is important to realize that theories are available to describe ignition only for the case of a uniform heating of a planar face [18]. ISO has recently adopted a radiant exposure ignitability test, ISO 5657 [19] (Figure 3). The Cone Calorimeter, discussed in detail below under heat release rate methods, also provides this same needed measuring capability [20]. Recent work [21] has shown that this method leads to useful, high quality ignition data, although the ultimate goal of complete apparatus-independence of results may never be achieved with a real instrument. Similarly, the LIFT apparatus for flame spread testing, discussed below, can also 
be used to obtain radiant ignition data. The ISO 5657 method provides for testing specimens which are in a horizontal orientation, the LIFT apparatus tests specimens oriented vertically, while the Cone Calorimeter is used for testing in either orientation.

Since radiant ignitability is only a small component of the fire development process, programs have not been formulated to provide direct large-scale validation for the bench-scale data. Some incidental comparisons, however, have been made during the course of a Lund University study on room fire on room fires [22].

\section{FLAME SPREAD}

In most fires there is a period where the material gets progressively involved by a gradual spreading of flame. Thus, it is important to be able to characterize this flame spread process. Several standard test methods are available, but the results are given as ratings on arbitrary scales and cannot be analyzed within the current-day fire modeling capabilities. Lacking this, such data cannot be reinterpreted in the context of a new design geometry. Newer tests for flame spread are being developed. The most prominent example is a method originally developed by the International Maritime Organization (IMO) [23]. A modified version of this method has since resulted in an ASTM standard [24] and also a proposed ISO one [25]. The analysis and data treatment for this test (in its ASTM or ISO variants, but not in the IMO version) have been done according to a theory of flame spread [26]. The test apparatus has been named LIFT, for Lateral Ignition and Flame spread Test, and is shown in Figure 4.

It might be noted, however, that the full incorporation of appropriate flame spread features into room fire models has proven to be a most difficult task, although significant progress is being made for walls [22],[27] and for upholstered furniture items [28]. Actual determination of flame spread rates requires an apparatus, such as the LIFT, especially dedicated to this task. In the case of many room fires, however, what is desired is not a detailed measure of the local flame spread rates, but, rather, an overall expression for fire growth (which is composed of the individual heat release contributions by specific parts of each burning item). Such information is, in fact, available as a measurement from the Cone Calorimeter, and is discussed in one of the examples below.

Actual instances of validation of LIFT apparatus data against large-scale room fires are not yet available, although the study at Lund University has correlated some LIFT data [22].

\section{HEAT RELEASE - BENCH-SCALE}

Measurement of heat release in bench-scale is not new. For instance, ASTM has a method on the books (ASTM E 906, the OSU Calorimeter-[29]) which was originally developed around 1970. Its results, however, when compared against other measurement methods, have been found to substantially underestimate the heat release rate [30]. A number of other instruments were also designed during the 1970's, but were limited because of either poor validity or practical operational difficulties. With oxygen consumption calorimetry coming into use, however, it became obvious that an entirely new instrument should be built which is specifically designed to make use of this principle.

The development work led to a practical instrument, known as the Cone Calorimeter. The apparatus (Figure 5) makes use of an electric heater in the form of a truncated cone, hence its name. The apparatus is a general-purpose one, which may be used to test products for various applications. Thus, the heater had to be capable of being set to a wide variety of heating fluxes; the actual 
capability spans 0 to $100 \mathrm{~kW} / \mathrm{m}^{2}$. The design of the heater was influenced by an earlier ISO test on radiant ignition, ISO 5657 [31]. The requirements for the Cone Calorimeter went beyond the design parameters of the ISO 5657 cone, thus the actual heating cone in the Cone Calorimeter is a new design. The Cone Calorimeter represented such a significant step forward in fire testing instrumentation that it was awarded the prestigious R\&D.100 award in 1988 [32]. The technical features are documented in several references [33], [34], [35], and [36]. Here, we will merely point out some of the most salient features:

- horizontal or vertical specimen orientation

- composite and laminated specimens can be tested

- continuous mass loss load cell readings

- feedback-loop controlled heater operation

- heat flux calibration by heat flux meter with in-built alignment fixture

- heat release rate calibration using methane metered with mass flow controller

- smoke measured with laser-beam photometer and also gravimetrically

- provision for analyzing $\mathrm{CO}, \mathrm{CO}_{2}, \mathrm{H}_{2} \mathrm{O}, \mathrm{HCl}$, and other combustion gases

The method is known as ISO DIS 5660 [20] or as ASTM E 1354 [37]. The equipment is made by 5 different manufacturers and is now used by over 40 laboratories worldwide.

Data from bench-scale heat release rate measurements are reported in $\mathrm{kW} / \mathrm{m}^{2}$. The extra $\mathrm{m}^{2}$, compared to the full-scale results, comes from the fact that in the full scale, one is interested in the total heat being produced by the burning object. In bench scale, by contrast, the area of the specimen has no intrinsic significance, and results have to be reported on a per-unit-area basis. To go from bench-scale data to full-scale predictions, then, requires that an ' $\mathrm{m}^{2}$ factor' be supplied. This factor - in the simplest case of uniformly burning materials - is the area of flame involvement, at any given time of the fire. Today's methods for estimating the full-scale heat release rates do not, typically, treat this area-of-flame-involvement factor explicitly, but rather subsume it into the general predictive correlation.

Validation of bench-scale heat release rate data against large-scale fires has been successfully undertaken in several instances; details are discussed below.

\section{SMOKE}

Typically, the methods for measuring smoke in bench-scale have been closed box methods. Two of those are in common use - the NBS single-chamber test (ASTM E 662) [38] and the dualchamber test developed in Germany. Both of these methods have been under consideration by ISO [39], [40]. The dual-chamber test has been used in Germany, Holland, and Italy, while the NBS test has been used in numerous countries worldwide. Nonetheless, a study showed that any closed-box type test has some very pronounced intrinsic limitations [35]. Thus, it became appropriate to consider a test with a flow-through geometry. Since the Cone Calorimeter already had other needed prerequisites (well-controlled uniform irradiance, accurate load cell, good control of airflow rates, etc.) it was decided to base a new smoke measuring apparatus on the combustion system already available with the Cone Calorimeter. Figure 6 shows a view of the laser-beam photometer which is used. The photometer uses monochromatic, rather than white, light, since it was shown that substantial errors can occur when using the Beer-Lambert law with white light sources [41]. The system is also notable in that windows (which are a substantial source of drift in those apparatuses 
where they are used) are not needed because of a pressure-difference purging arrangement. A discussion of the other design details is given in [35].

The Fire Research Station recently evaluated a number of bench-scale instruments for measuring smoke, and found that the Cone Calorimeter arrangement was subject to the least measurement bias [42].

The bench-scale smoke data are reported in the form of specific extinction area. This is defined as the area $\left(\mathrm{m}^{2}\right)$ of smoke generated per mass $(\mathrm{kg})$ of specimen decomposed; thus the units are $\mathrm{m}^{2} / \mathrm{kg}$. The above quantity is measured by determining the extinction in natural-log units, according to the equations provided in [35]. It must be emphasized that load cell measurements are needed so that the specimen mass loss rate can be included. This variable is based on a theoretically sound analysis of the optical properties of fire smokes, and is not simply an arbitrary index, as has been used with some other smoke tests.

In large-scale tests, the measurement issues are generally similar. Early versions of the Furniture Calorimeter [13] used a simple white-light beam. In more recent years, a laser beam photometer very similar to the one used with the Cone Calorimeter is being fitted to furniture calorimeters and exhaust ducts associated with room fires [43].

Data analysis from large-scale tests can proceed in two different ways. For furniture calorimeter tests, where load cell data are usually available, the analysis can be done in exactly the same way as for the bench-scale data. This is sometimes referred to as the yield of smoke, since it is the extinction area generated per unit specimen mass. In the case of room fires, load cell data are usually not available. Even if load cell data are available, in many cases it is desired to evaluate fire hazard according to the total amount of smoke produced. This is termed the production of smoke, and is meaningful only as an integral over the entire test period. In other words, the extinction area flowing by the measurement location per second $\left(\mathrm{m}^{2} / \mathrm{s}\right)$ is integrated over time to give the total production $\left(\mathrm{m}^{2}\right)$. The instantaneous values of $\mathrm{m}^{2} / \mathrm{s}$ are generally not used directly by themselves.

In addition to being described by its optical properties, smoke can also be measured as the amount of soot generated on a gravimetric basis. Soot measurements can be done equally well in large scale or in bench scale. The soot amount is measured by sampling a small fraction of the exhaust gas stream and collecting its soot on an inert filter. The filter is weighed to determine the soot deposited. The analysis, then, involves determining the yield of soot as (mass soot generated/mass specimen lost). Since the units for soot yield are $\mathrm{kg} / \mathrm{kg}$, they are dimensionless. Under certain circumstances there is linear relationship between the soot yield and the specific extinction area (smoke yield); Ref. [35] gives details of this relationship.

The validation of bench-scale smoke data against the full scale is still in its infancy. For optical measurements, the normal procedure would be to compare the test-average smoke yield (total $\mathrm{m}^{2}$ smoke produced/total $\mathrm{kg}$ of specimen mass lost). Note that this is not equivalent to simply averaging the instantaneous yield readings over time, since a mass-weighted average is effectively required. For gravimetric soot measurements, the yields would be directly compared for bench scale against full scale. Some initial efforts have recently been reported [44], [35], but comprehensive validation efforts still remain to be attempted. 


\section{CORROSIVE PRODUCTS}

The widespread realization of the importance of fire damage through corrosion dates, perhaps, to a conference [45] organized in Sweden in 1969. During the intervening years, a number of tests for the corrosivity of combustion products have been proposed. These typically were simple $\mathrm{pH}$ tests. On an even more extreme basis, some regulatory bodies have taken steps to restrict usage of materials based solely on the content of halogen atoms $(\mathrm{Cl}, \mathrm{Br}$, etc.), without any consideration of actual corrosion performance. The first actual performance test to achieve recognition was a test developed by the French telecommunications agency CNET. The method [46], like most recent efforts in this area, focuses exclusively on damage to electronic equipment, since this has been the area of the greatest public concern. It involves a single, closed box, which contains a test sample, a beater, and a target. The target is a printed circuit board; the performance measured is the increase in the resistance of the circuit trace. This increase is taken to be an indication of metal loss due to corrosion.

Recently ASTM appointed a Task Group, ASTM E5.21 T.G. 70, to study available fire corrosivity tests and to make recommendations. The task group, while finding the CNET test to be the best of the currently available methods, did not feel that it was a fully satisfactory performance test. The reasons had to do with practical difficulties in testing, with heating conditions which were considered unrealistic, and with inadequacies of both the target and its measurement technique. The Task Group made a number of recommendations, including the fact that it saw the need for a '3-part' target. It was felt that in addition to measuring simple loss of metal, a practical test method should also measure two other aspects of non-thermal fire damage: ohmic bridging (which can short out electric circuits), and contact fouling (which can make relay and switch contacts non-functional). While the Task Group has not yet finished its work, it has commissioned a number of exploratory experiments and has proposed a candidate method [47].

Figure 7 shows the method as currently envisioned. The Task Group considered various apparatus configurations and is currently working with a system where the combustion chamber is of a flowthrough type, with the target exposure chamber being a large sampling syringe. The syringe is filled using a servo-controlled stepper motor, so that the filling time coincides with the actual specimen burning time. The syringe is then closed, disconnected, and allowed to remain for $24 \mathrm{~h}$ in a temperature-controlled room. The actual target has three pieces: a serpentine trace for metal loss, a set of discontinuous traces for ohmic bridging, and sets of relay contacts for contact fouling determinations. Electrical measurements are made on the target after the $24 \mathrm{~h}$ period has elapsed. The method has not been fully realized yet, and substantive changes may still be made by the Task Group.

As far as validation goes, there is currently no reliable full-scale data base against which bench-scale methods might be validated. Full-scale tests have been few and ad hoc.

\section{TOXIC PRODUCTS}

Over the last two decades, the design of a suitable bio-assay apparatus for measuring the toxic potency of combustion products has interested quite a few researchers. Several dozen of these methods have been described in the literature; the better-known ones have been reviewed in depth in [48]. More recently, an approach, the 'N-Gas Model,' has been described [49] where primary reliance is placed on analytical gas measurements, with a bio-assay test only being used to check against anomalous results. While minimizing the dependence on animal testing, this still requires that 
a suitable bio-assay apparatus be available. In the last several years the number of suggested new designs has rather decreased. Most recently there is a substantial amount of effort being put into work with a radiant furnace apparatus. This apparatus was first developed at the Weyerhaeuser Company [50] as a modification of the earlier cup furnace method developed at the National Bureau of Standards [51]. Further development then continued at the Southwest Research Institute (SwRI). In 1987 the National Institute of Building Sciences (NIBS) commissioned SwRI to develop the apparatus further [52]. NIBS desired, in fact, not simply an improved apparatus for actual measuring of toxic potencies $\left(\mathrm{LC}_{50}\right.$ 's), but a method which would use a hazard index for rating products. The product rating, in the NIBS approach, would be a result on this index scale, not a numerical $\mathrm{LC}_{50}$ value.

At NIST it was also recognized that it is very desirable to measure additional properties of products, beyond the $\mathrm{LC}_{50}$, since it was clear that the $\mathrm{LC}_{50}$ by itself was not an accurate measure of the relative toxic fire hazard of products. In pursuit of that goal, an analysis was made, showing that a rational measure (instead of solely an arbitrary index) could be obtained if, in addition to the $\mathrm{LC}_{50}$, two additional properties were measured. The properties needed were the time to ignition and the average mass burning rate [53]. The reason that such other variables are needed is that the hazard from the combustion products must include not only the $\mathrm{LC}_{50}$ of the item, but also its actual burning rate.

At the time that NIST was proposing this approach, the required measurements had to be made using several different apparatuses. Subsequently, it was realized that the apparatus which was developed by SwRI for NIBS could be adapted for making all the needed measurements in a single apparatus. Figure 8 shows the apparatus. The details of the protocol needed to achieve this are still being developed at both SwRI [54] and NIST. It is perceived that one major advantage of this method, if successfully developed, would be its capability to characterize composite specimens. Of course, the hazard in a building resulting from the toxicity of the combustion products depends on the geometry and fire safety features of the building, and not solely on the material properties of the burning combustibles; thus, such a protocol can only be a correct indication of the toxic hazard once the influence of these other factors has been considered.

Validation of bench-scale fire toxicity data against the full scale has been a vigorously debated issue in recent years [55]. Since the issues have not been resolved in any definite way, during 1989 . 90 NIST has been conducting a pilot project [56] to establish the proper bases for such a validation effort and to illustrate the approach with some experimental data. The intended result of this work is not, in itself, to produce a list of validated and non-validated methods, but rather to recommend a suitable strategy by which such validations could be carried out.

\section{EXAMPLES OF PREDICTIVE CORRELATIONS}

While many of the methods described above are new enough that complete, predictive correlations have not yet been achieved, there are several success stories which can be presented already. It will be noted that in each case it is essential to restrict the scope to a particular class of product or commodity. Important aspects of the large-scale fire scenario, of geometric orientation effects, of heat transfer details, etc., are grouped together into the constant(s) of the predictive correlation. Thus, for example, it should certainly not be expected that a method developed for upholstered furniture items be suitable for describing ceiling tile behavior. Such a need for product-class-specific correlations will disappear some day in the future when full computer fire modeling can replace the 
present correlation methods; for the moment, however, the user will have to clearly keep in mind what each method can and cannot do.

Example 1 - Prediction of upholstered furniture fires with the Cone Calorimeter

One of the earliest examples of a successful application of these principles has been in the area of upholstered furniture. The initial full-scale data were obtained at NBS in the Furniture Calorimeter. For upholstered furniture, the desired full-scale variable to be predicted is the peak rate of heat release. In developing a bench-scale data correlation, however, it must be emphasized that the proper bench-scale quantity is not necessarily the peak value, but may be a time-average. The actual best-fit average was, in fact, for a $180 \mathrm{~s}$ bench-scale rate of heat release average [57]. The way to understand this is that, during the peak burning in full scale, not all portions of the specimen's surface are undergoing their peak burning. Some portions are not yet ignited, some are mid-way through burning, while others may be already burned out. In addition to the bench-scale measurement of the beat release rate, other data needed for the predictive correlation are descriptors of the full-scale specimen: mass, frame construction, and the shape or the style of the article. Figure 9 shows the over-all success of this study. Even though flame spread plays an important role in this problem, it should be noted that it was not expressly modeled. Good results were, nonetheless, achieved since there is a high degree of intrinsic correlation between flame spread and rate of heat release behavior. An explicit inclusion of flame spread might improve the correlation even more, although it is not clear if the additional testing burden would be justified.

\section{Example 2 - Prediction of Room/Corner fires with the Cone Calorimeter}

Another area where a completed example is available is the flammability of room wall and ceiling linings. Wickstrom and Goransson [58] have suggested a method for predicting the heat release rate of Room/Corner Tests, based on data from the Cone Calorimeter. A similar, but somewhat more complex method also been developed for the same purpose by Magnusson and Sundstrom [59]. The Wickstrơm-Gorransson method is designed to predict the full-scale heat release rate. It is based on the assumption that the actual flame spread rate depends on the ignition time obtained in the bench-scale test only. Further, the heat release rate per unit area in the full scale is assumed to vary with time in the same manner as in the bench scale. Thus, a convenient superposition technique is derived which considers the entire heat release process. Both the ignition time and the heat release rate are measured in bench scale by the Cone Calorimeter. The method has been applied to nine products tested in the Cone Calorimeter [60] and compared against full-scale data from the NORDTEST Room/Comer Test. Figure 10 shows that the success of this method in predicting full-scale heat release rate histories. In view of the fact that the algorithms used are quite simple and the phenomena being represented are difficult and complex, their success must be viewed as outstanding.

\section{CONCLUSIONS AND FUTURE DIRECTIONS}

Existing older tests for many aspects of fire testing have been found deficient when examined from a current engineering standpoint. Substantive progress has been made recently in developing more valid tests in several areas. These include heat release rate and smoke tests in bench-scale, in largescale open burns (furniture calorimeter), and in full room scale. Bench-scale methods for ignitability and flame spread are also available for use. Bench-scale tests for corrosive products and for toxic products are still in the process of active design. Validation efforts are farthest along in the heat 
release area. Some limited success has been achieved with validations of smoke tests. Validation procedures for toxic products are actively being studied, while validation for corrosive products has not yet been tackled. In the next few years we expect that validation exercises will be undertaken and predictive methods developed for a number of other product categories.

Finally, we must conclude with a point of prudent caution. For fire protection as a whole, benchscale tests will rarely constitute a complete and total replacement for full-scale testing. Because a bench-scale test treats a specimen which is very small compared to the actual construction, it may not represent all the full-scale phenomena which may be occurring during a fire. By itself, this is not a serious limitation, since full-scale testing also does not take into account what might happen under every conceivable full-scale fire scenario! What does need to be considered is if there are areas which are both crucial to the fire safety evaluation, and which also are ones which cannot be properly studied in bench scale. Such examples so far have been noted primarily in the area of thermostructural failures of non-structural members. For instance, the fire behavior of foam plastic ceiling materials depends crucially on whether the material stays and burns in place, or whether it falls off and burns on the floor [61]. For any practical method of predicting a product's full-scale performance, there may also be additional limitations on the bench-scale technique developed, and, if so, these will need to be clearly stated as part of the method.

\section{REFERENCES}

[1] Fire Test Standards, Second Edition, American Society for Testing and Materials, Philadelphia (1988).

[2] Bukowski, R.W., Peacock, R.D., Jones, W.J., and Forney, C.L., Technical Reference Guide for the HAZARD I Fire Hazard Assessment Method (NIST Handbook 146, 3 Volumes). [U.S.] Natl. Inst. Standards and Technology (1989).

[3] Federal Trade Commission Complaint on the Flammability of Plastic Products, File No. 7323040, May 31, 1973.

[4] Emmons, H.W., Sci. Amer. 231, 21-27 (July 1974).

[5] Ostman, B., and Nussbaum, R., National Standard Fire Tests in Small Scale Compared with the Full-Scale ISO Room Test (Rapport I 870217), Trăteknik Centrum, Stockholm (1987).

[6] Proposed Standard Method for Room Fire Test of Wall and Ceiling Materials and Assemblies, 1982 Annual Book of ASTM Standards, Part 18. American Society for Testing and Materials, Philadelphia (1982).

[7] Surface Products: Room Fire Tests in Full Scale (Nordtest Method NT FIRE 025). NORDTEST, Helsingfors, Finland (1986).

[8] Room Fire Test in Full Scale for Surface Products, ISO DP 9705, International Organization for Standardization (1989).

[9] Huggett, C., Estimation of Rate of Heat Release by Means of Oxygen Consumption Measurements, Fire and Materials. 4, $61-5$ (1980). 
[10] National Fire Protection Association, Fire Protection Handbook, 16th edition, Section on Tables and Charts, NFPA, Quincy, MA (1986).

[11] Parker, WJ., Calculation of the Heat Release Rate by Oxygen Consumption for Various Applications, J. Fire Sciences. 2, 380-395 (1984).

[12] Babrauskas, V., Upholstered Furniture Room Fires - Measurements, Comparison with Furniture Calorimeter Data, and Flashover Predictions, J. of Fire Sciences. 2 5-19 (1984).

[13] Babrauskas, V., Lawson, J.R., Walton, W.D., and Twilley, W.H., Upholstered Furniture Heat Release Rates Measured with a Furniture Calorimeter (NBSIR 82-2604). [U.S.] Natl. Bur. Stand. (1982).

[14] Upholstered Furniture: Burning Behaviour - Full Scale Test. (NT FIRE 032). NORDTEST, Helsinki, Finland (1987).

[15] Babrauskas, V., Bench-Scale Methods for Prediction of Full-Scale Fire Behavior of Furnishings and Wall Linings, Technical Report 84-10, Society of Fire Protection Engineers (1984).

[16] Babrauskas, V., pp. 31-41 in Spacecraft Fire Safety (NASA Conference Publication 2476), NASA Lewis Research Center, Cleveland, OH (1986).

[17] Tests for Measuring 'Reaction-to-fire' of Building Materials, their Development and Application, ISO DTR 3814, (1986).

[18] Martin, S.B., pp. $877-896$ in Tenth Symp. (Intl.) on Combustion, The Combustion Institute, Pittsburgh (1971).

[19] Fire tests - Reaction to fire - Ignitability of building products, ISO 5657-1986(E), (1986).

[20] Draft International Standard - Fire Tests - Reaction to Fire - Rate of Heat Release from Building Products (ISO DIS 5660). International Organization for Standardization, Geneva.

[21] Babrauskas, V., and Parker, W.J., Fire and Materials. 11, $31-43$ (1987).

[22] Karlsson, B., Room Fires and Combustible Linings (Report SE-LUTVDG/TVBB-3050). Department of Fire Safety Engineering, Lund University, Lund, Sweden (1989).

[23] Rec. on Fire Test Procedures for Surface Flammability of Bulkhead and Deck Finish Materials. Res. A.564(14), suppls. Res. A.516(13), A.166(ES.IV). International Maritime Organization, London (1986).

[24] Standard Test Method for Determining Material Ignition and Flame Spread Properties (E 1321). American Society for Testing and Materials.

[25] Fire tests - Reaction to fire - Surface spread of flame of building products - Part I Vertical specimen (ISO DP 5658). 
[26] Quintiere, J.G., and Harkleroad, M.T, New Concepts for Measuring Flame Spread Properties, pp. 239-267 in Fire Safety Science and Engineering (ASTM STP 882), American Society for Testing and Materials, Philadelphia (1985).

[27] Mitler, H.E., Predicting the Spread Rates of Fires on Vertical Surfaces, accepted for publication, 23rd Symp. (IntL.) on Combustion, The Combustion Institute, Pittsburgh (1990).

[28] Dietenberger, M.A., Technical Reference and User's Guide for FAST/FFM Version 3, University of Dayton Research Institute, Dayton (1989).

[29] Standard Test Method for Heat and Visible Smoke Release Rates for Materials and Products (ASTM E 906), American Society for Testing and Materials, Philadelphia.

[30] Babrauskas, V., Comparative Rates of Heat Release from Five Different Types of Test Apparatuses, J. of Fire Sciences. 4, 148-159 (1986).

[31] Fire tests - Reaction to fire - Ignitability of building products (ISO 5657), International Organization for Standardization, Geneva (1986).

[32] 1988 R\&D•100 Award Winners, Research \& Development. 30, $62-104$ (October 1988).

[33] Babrauskas, V., Development of the Cone Calorimeter - A Bench Scale Heat Release Rate Apparatus Based on Oxygen Consumption, Fire and Materials. 8, 81-95 (1984).

[34] Babrauskas, V., and Parker, W.J., Ignitability Measurements with the Cone Calorimeter, Fire and Materials. 11, 31-43 (1987).

[35] Babrauskas, V., and Mulholland, G., Smoke and Soot Data Determinations in the Cone Calorimeter, pp. 83-104 in Mathematical Modeling of Fires (ASTM STP 983). American Society for Testing and Materials, Philadelphia (1987).

[36] Babrauskas, V., The Cone Calorimeter - Fire Properties, pp. 78-87 in New Technology to Reduce Fire Losses \& Costs, S.J. Grayson and D.A. Smith, eds., Elsevier Applied Science Publishers, London (1986).

[37] Standard Test Method for Heat and Visible Smoke Release Rates for Materials and Products using an Oxygen Consumption Calorimeter (E 1354). American Society for Testing and Materials, Philadelphia.

[38] Standard Test Method for Heat and Visible Smoke Release Rates for Materials and Products (ASTM E 906), American Society for Testing and Materials, Philadelphia.

[39] Plastics - Smoke generation - Single chamber test. Part 1: Determination of specific optical density (DP 5659). ISO/TC 61/SC 4/WG 2/N 19 (1989).

[40] Fire Tests - Reaction to Fire - Smoke Generated by Building Products (Dual Chamber Test). Draft International Standard DIS 5924 (ISO/TC 92/SC 1/WG 4/N 64), 1986.

[41] Mulholland, G., How Well Are We Measuring Smoke?, Fire and Materials. 6, $65-67$ (1982). 
[42] Morgan, H., and Geake, PJ., Smoke Particle Sizes: A Preliminary Comparison between Dynamic and Cumulative Smoke Production Tests, Fire Research Station, Borehamwood, England (1988).

[43] Upton, S., Fire Testing Technology, London, private communication.

[44] Mulholland, G.M., Henzel, V., and Babrauskas, V., The Effect of Scale on Smoke Emission, pp. 347-357 in Fire Safety Science - Proc. of the Second International Symposium (1988). Hemisphere Publishing, New York (1989).

[45] SKYDD 69 (Protection 69): Plastics - Fire - Corrosion, Proc. Intl. Symp. and 15th Nordic Fire Protection Day, Stockholm, April 23, 1969, Swedish Fire Protection Association, Stockholm (October 1969).

[46] Fire Performance: Determination of the Corrosiveness of Effluents (158 CNET/LAB/SER/ENV). National Centre for Telecommunications Studies (CNET), France (1983).

[47] Ryan, J.D., Babrauskas, V., O'Neill, TJ., and Hirschler, M.M., Performance Testing for the Corrosivity of Smoke, pp. 75-88 in Characterization and Taxicity of Smoke (STP 1082), American Society for Testing and Materials, Philadelphia (1990).

[48] Kaplan, H.L., Grand, A.F., and Hartzell, G.E., Combustion Toxicology. Technomic Publishing, Lancaster, PA (1983).

[49] Babrauskas, V., Levin, B.C., and Gann, R.G., A New Approach to Fire Toxicity Data for Hazard Evaluation, ASTM Standardization News. 14, 28-33 (Sept. 1986).

[50] Alexeeff, G.V., and Packham, S.C., Use of a Radiant Furnace Fire Model to Evaluate Acute Toxicity of Smoke, J. Fire Sciences. 2, 306-320 (1984).

[51] Levin, B.C., Fowell, A.J. Birky, M.M., Paabo, M., Stolte, A., and Malek, D., Further Development of a Test Method for the Assessment of the Acute Inhalation Toxicity of Combustion Products (NBSIR 82-2532). [U.S.] Natl. Bur. Stand. (1982).

[52] Grand, A.F., Development of a Product Performance Combustion Toxicity Test (SwRI Project 01-1744-001), final report to be issued. Southwest Research Institute, San Antonio, TX.

[53] Babrauskas, V., Toxic Hazard from Fires: A Simple Assessment Method, pp. 16.1 to 16.10 in Fire: Control the Heat...Reduce the Hazand, QMC Fire \& Materials Centre, London (1988).

[54] Grand, A.F, personal communication, Southwest Research Institute, San Antonio, TX (1989).

[55] Braun, E., Gann, R.G., Levin, B.C., and Paabo, M., Combustion Product Toxic Potency Measurements: Comparison of a Small Scale Test and "Real-World" Fire, J. Fire Sciences. 8, 63-74 (1990). 
[56] Babrauskas, V., Harris, R.H., Jr., Braun, E., Levin, B.C., Paabo, M., and Gann, R.G., The Role of Bench-Scale Test Data in Assessing Full-Scale Fire Toxicity, report to be issued.

[57] Babrauskas, V., and Krasny, J.F., Fire Behavior of Upholstered Furniture (NBS Monograph 173). [U.S.] Natl. Bur. Stand. (1985).

[58] Wickstrơm, U., and Göransson, U., Prediction of Heat Release Rates of Large Scale Room Fire Tests Based on Cone Calorimeter Results, J. Testing and Evaluation. 15, 364370 (1987).

[59] Magnusson, S.E., and Sundstrơm, B., Combustible Linings and Room Fire Growth - A First Analysis, pp. 45-69 in Fire Safety: Science and Engineering (ASTM STP 882), T.Z. Harmathy, ed. American Society for Testing and Materials, Philadelphia (1985).

[60] Babrauskas, V., unpublished data.

[61] Morris, W.A, Hopkinson, J., and Malhotra, H.L., Fire Hazard of Expanded Polystyrene Linings (Fire Research Note No. 827), Fire Research Station, Borehamwood (1970). 

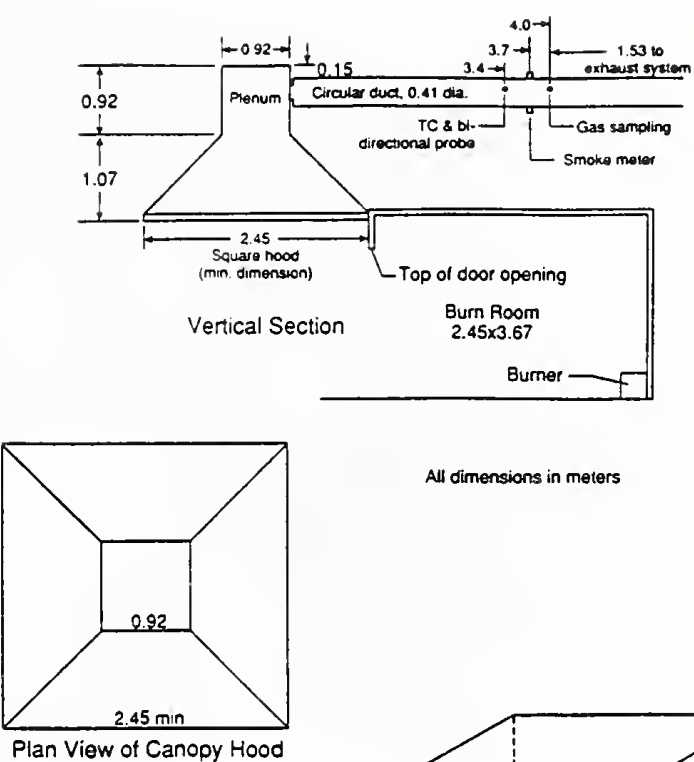

All dimensions in meters

Figure 1.

The ASTM room fire test
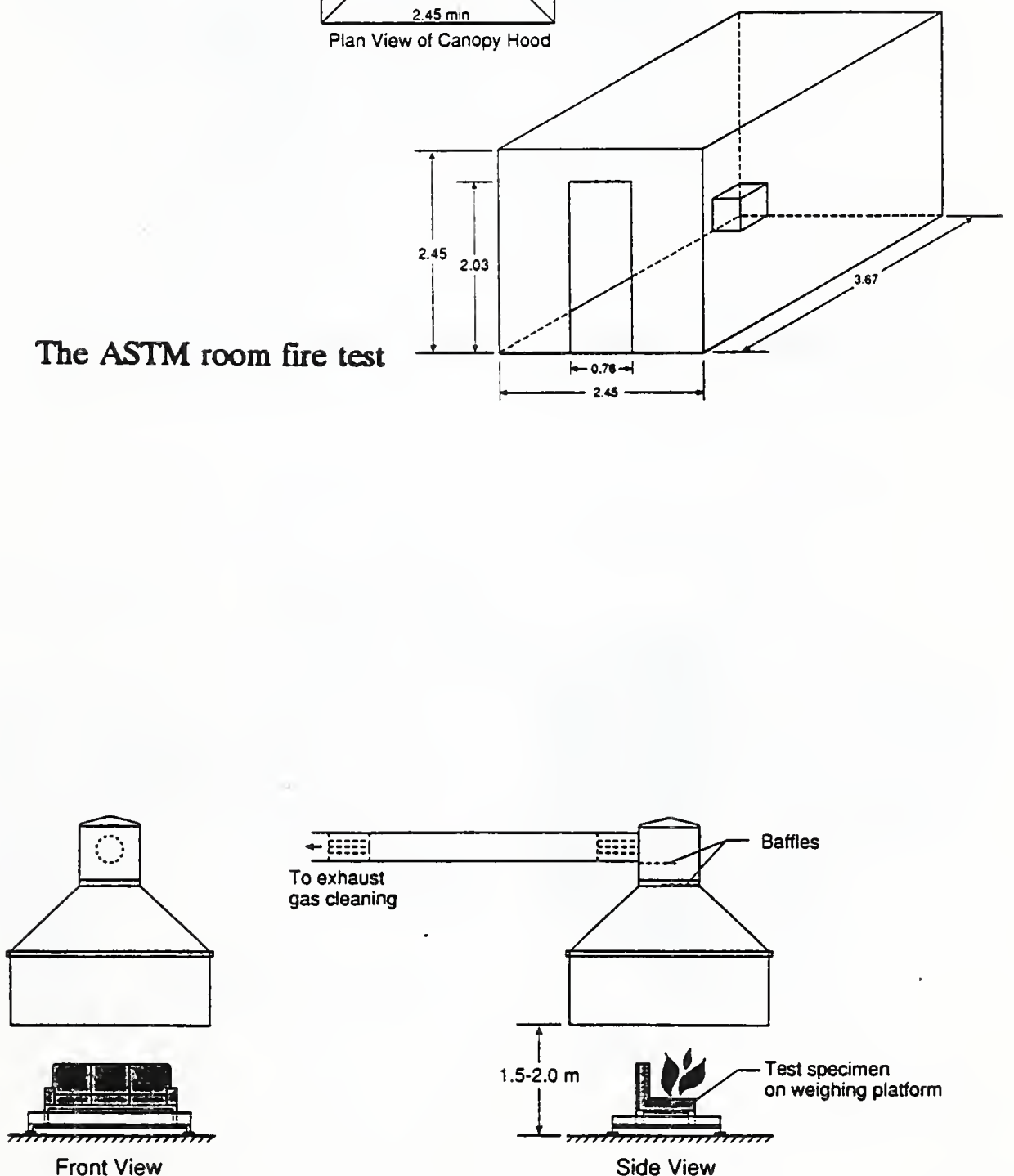

Figure 2.

The NORDTEST furniture calorimeter 


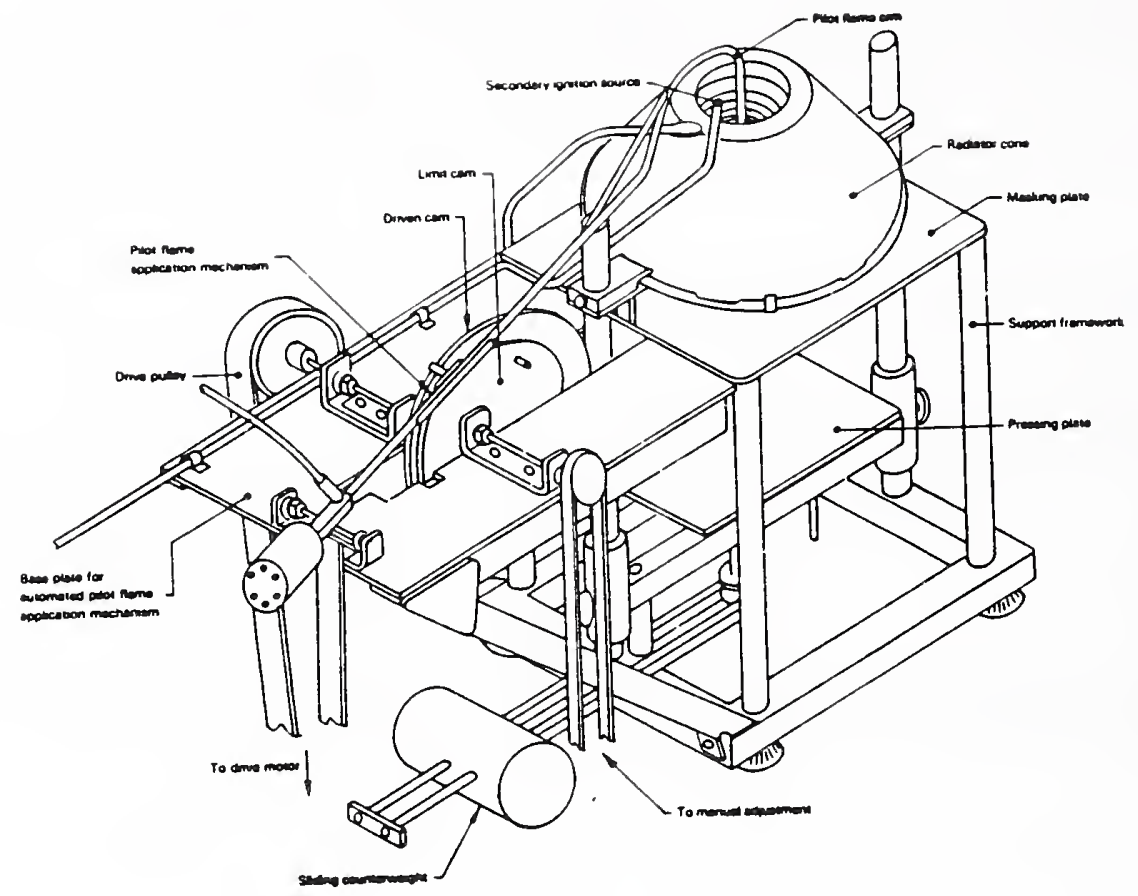

Figure 3. The ISO radiant ignition apparatus (ISO 5657)

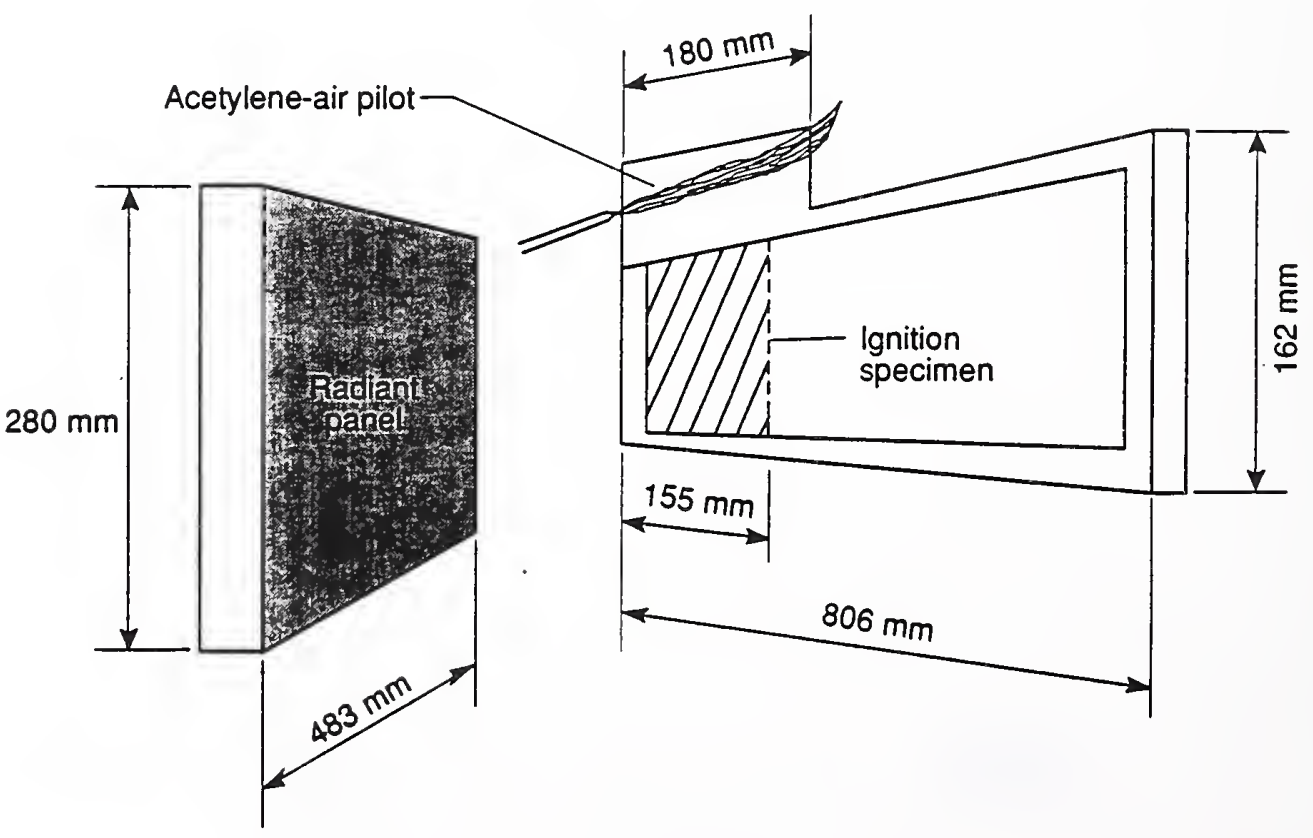

Figure 4. The LIFT apparatus for flame spread (ISO DP 5658; ASTM E 1321) 


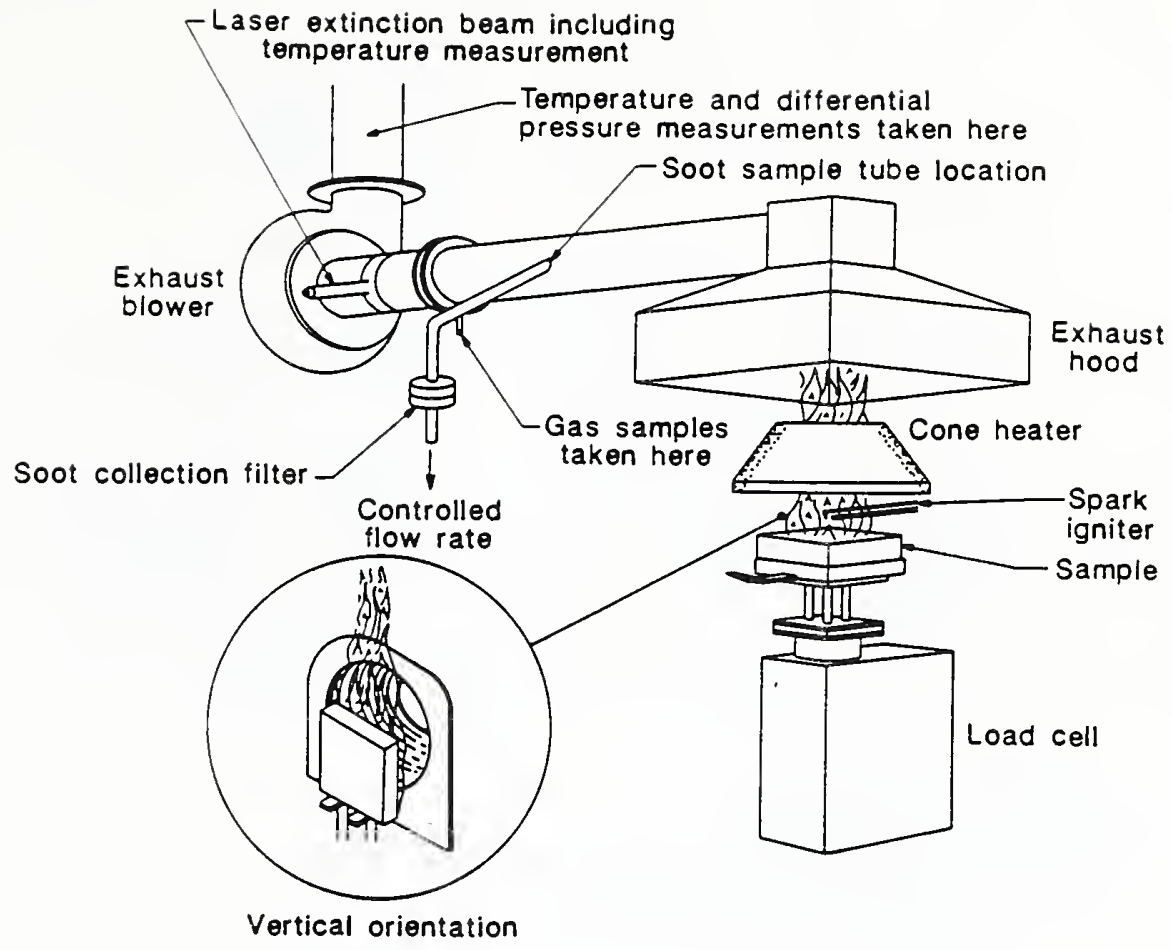

Figure 5. A schematic view of the cone calorimeter (ISO DIS 5660; ASTM E 1354)

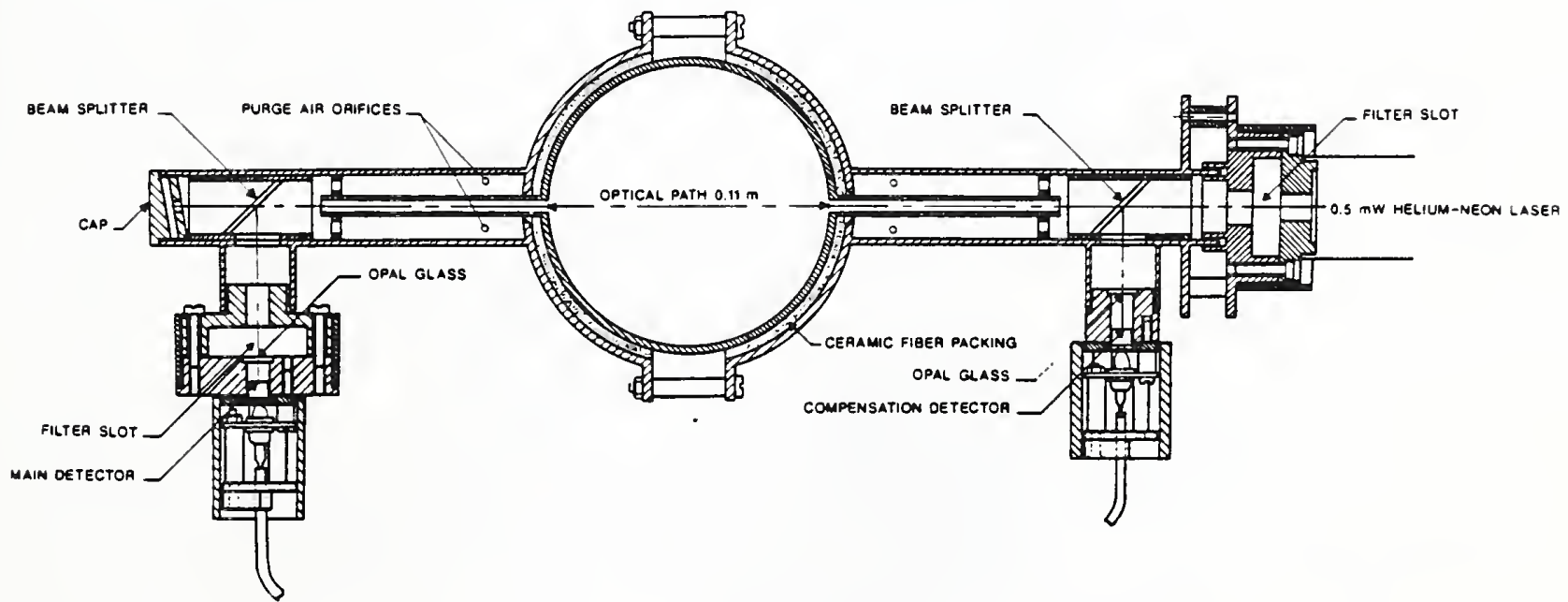

Figure 6. View of the smoke measuring system used with the cone calorimeter 
Standard: $1 \mathrm{~m}$ long, $100 \mathrm{~mm}$ I.D. (nom.) stainiess steel

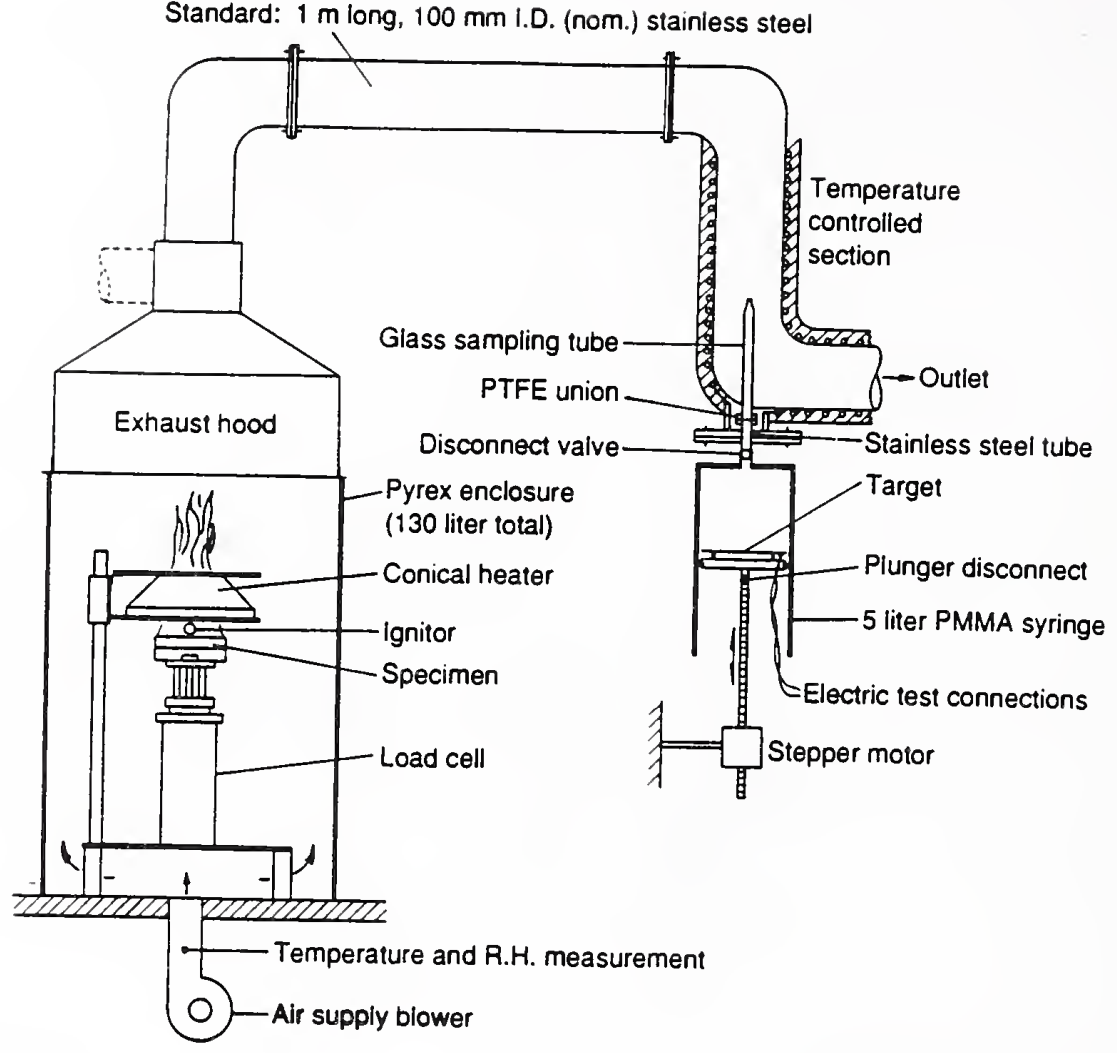

Figure 7.

View of smoke corrosion test being developed by ASTM E 5.21 TG. 70

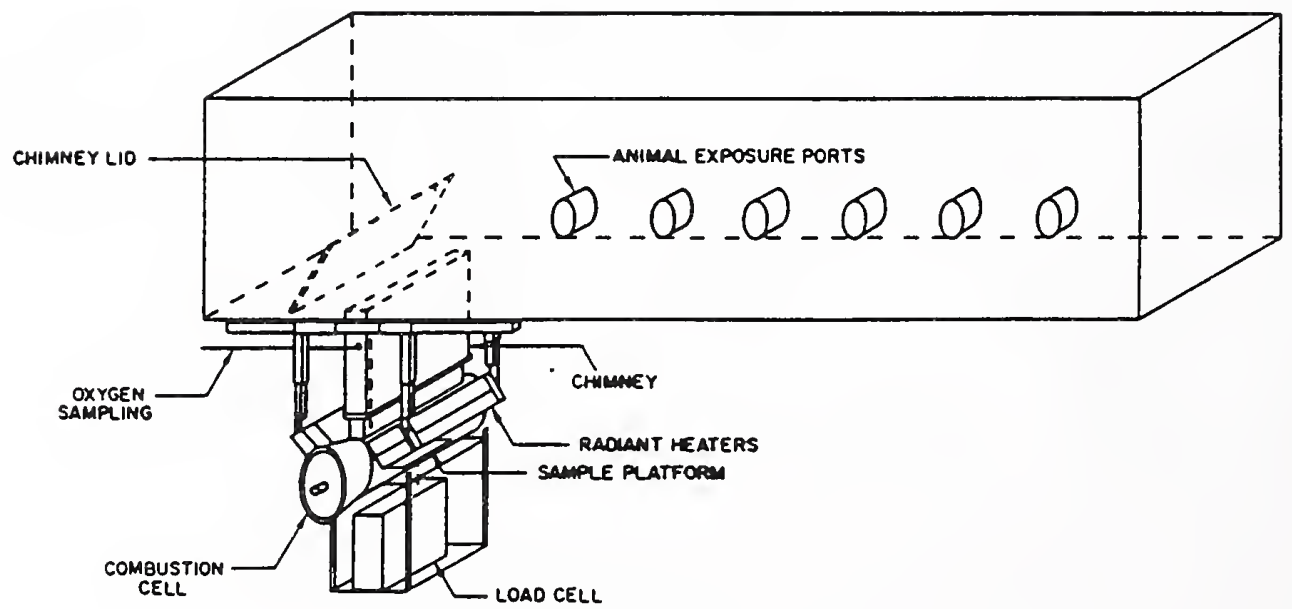

Figure 8.

The radiant furnace toxicity apparatus 


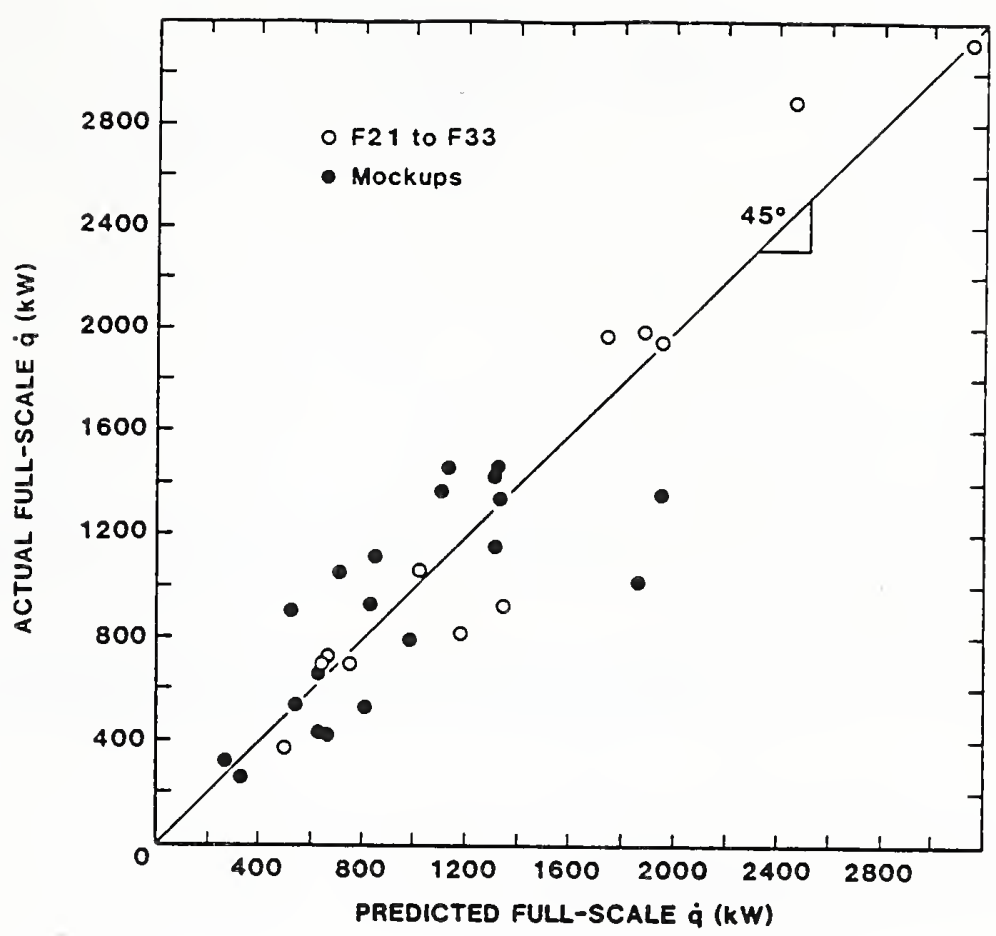

Figure 9. Comparison between predicted and actual heat release rate results for upholstered furniture

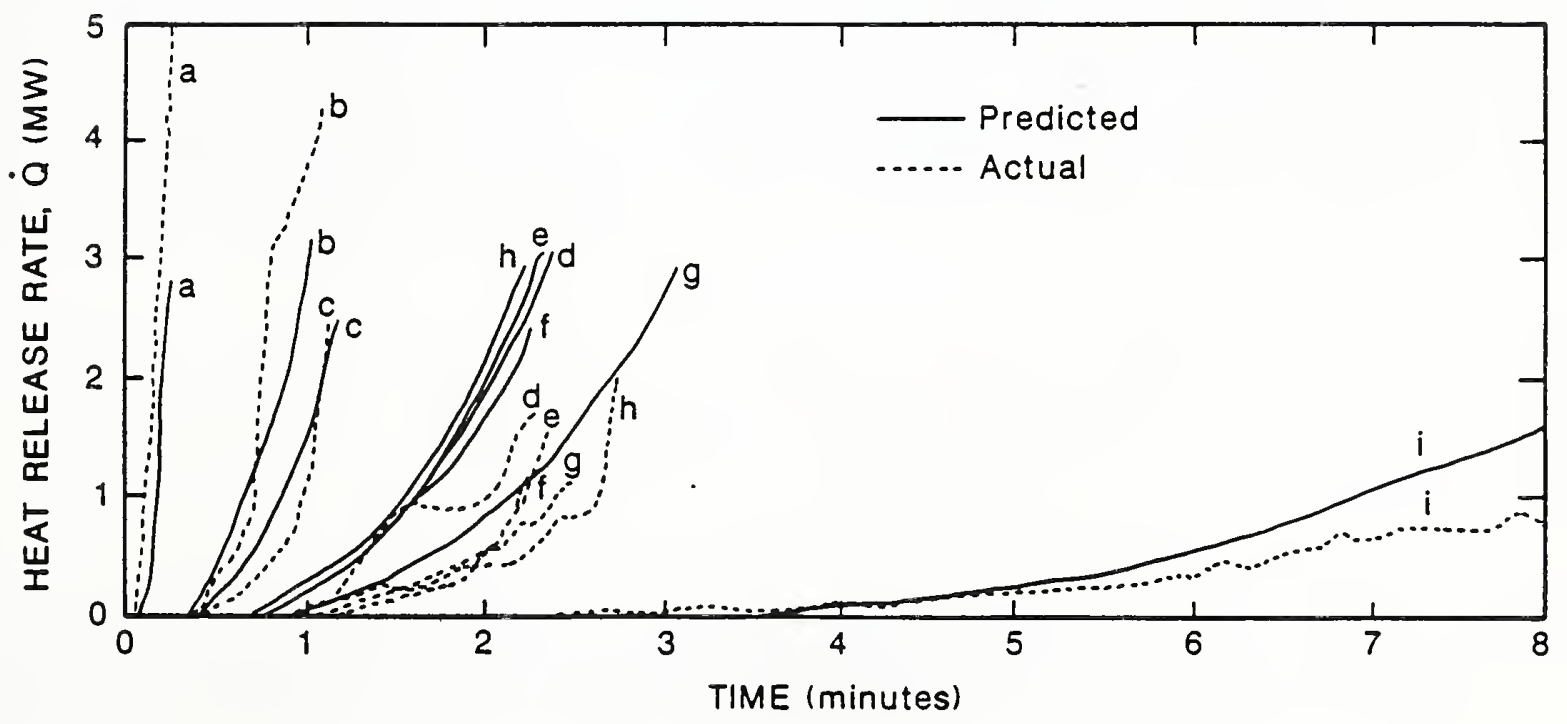

Figure 10. Prediction of combustible wall linings (notations $a$ through $i$ refer to 9 different materials tested, described in detail in [58]) 
. 


\begin{tabular}{|c|c|c|}
\hline \multirow[t]{4}{*}{$\begin{array}{l}\text { NIST-114A } \\
\text { (REV. 3-89) }\end{array}$} & \multirow{4}{*}{$\begin{array}{l}\text { U.S. DEPARTMENT OF COMMERCE } \\
\text { NATIONAL INSTITUTE OF STANDARDS AND TECHNOLOGY } \\
\text { BIBLIOGRAPHIC DATA SHEET }\end{array}$} & $\begin{array}{l}\text { 1. PUBLCATION OR REPORT NUMBER } \\
\text { NISTIR } 4326\end{array}$ \\
\hline & & 2. PERFORMING ORGAMIZATION REPORT NUMBER \\
\hline & & 3. PUBLCATION DATE \\
\hline & & JUNE 1990 \\
\hline
\end{tabular}

4. TITLE AND SUBTITLE

Modern Test Methods for Flammabilicy

5. AUTHOR(S)

Vytenis Babrauskas

6. PERFORMING ORGANIZATION (IF JOINT OR OTHER THAN NIST, SEE INSTRUCTIONS) U.S. DEPARTMEMT OF COMMERCE NATIONAL INSTITUTE OF STANDARDS AND TECHNOLOGY GAITHEASBURG, MO 20899

7. CONTRACT/GRANT MUMBER

8. TYPE OF REPORT AND PEAIOD COVEAED

9. SPONSORING ORGANIZATION NAME AND COMPLETE ADOAESS (STREET, CITY, STATE, ZIP)

10. SUPPLEMENTARY NOTES

DOCUMENT DESCRIEES A COMPUTEA PROGRAM; SF-185, FIPS SOFTWARE SUMMARY, IS ATTACHED.

11. AESTAACT (A 200-WOAD OR LESS FACTUAL SUMMARY OF MOST SIONIFICANT IMFOAMATION. IF OOCUMENT IMCLUDES A SIONIFICANT BIBLOGRAPMY OR UTERATURE SUAVEY, MENTION IT HERE)

During the last decade, significant improvements have become available in flammability testing. Rationaily-based new methods, derived from fundamental engineering principles are replacing the previously used empirical tests. The major emphasis in this development work has been to provide a basic set of bench-scale methods which can be used to predict full-scale producr performance. Reference methods for conducting fuli-scale tests will continue to be needed to handle products or situations where the bench-scale metnods are not applicable. The bulk of the testing needs, however, can now be fulfilled by use of bench-scale tests which are not only simple to run, but are known to accurately predict the full-scale performance.

12. KEY WORDS (6 TO 12 ENTAIES; ALPHABETICAL OADEA; CAPTALZE ONLY PAOPEA MAMES; AMD SEPARATE KEY WOADS BY SEMICOLONS) Bench-scale tests; fire corrosivity; fire toxicity; heat release race; smoke; rest methods 

